\title{
THE INFLUENCE OF AUDIT COMMITTEE AND OWNERSHIP STRUCTURE ON EARNINGS MANAGEMENT
}

\author{
Metta Kusumaningtyas ${ }^{\star}$ \\ Dessy Noor Farida \\ STIE Bank BPD Jateng
}

\begin{abstract}
The objective of this study is to analyze the influence of audit committee characteristics and ownership structure on earnings management. The characteristics which are used to measure the effectiveness of the audit committee are audit committee independence, audit committee competency, audit committee activity and audit committee size. Ownership structures are characteristics of public ownership, institutional ownership, and managerial ownership. Earnings management in this study were measured by using the value of discretionary accrual. The population in this study is manufacturing companies listed on the Indonesia Stock Exchange (BEI) in 2007-2012. Based on purposive sampling method, the number of samples in this study was 66 samples. Testing the hypothesis used multiple regression analysis. The results indicate that audit committee independent, audit committee size and institutional ownership had a significant negative effect on earnings management. Instead the others variables such as audit committee competency, audit committee activity, public ownership and managerial ownership did not influenced on earnings management.
\end{abstract}

Keywords: Earnings Management; Audit Committee; Ownership Structure

\section{INTRODUCTION}

The tendency of investors and other external parties that more focus on profit information, triggers management does dysfunctional behaviour in the form of earnings management or earnings manipulation to generate profit that is considered normal for a company (Gunny 2010), it can happen because accounting methods gives chances (Gumanti, 2004). Behaviour of this earnings manipulation also arise because of high information asymmetry between management and other party that does not have resources or information access that adequate to monitor the actions of management so that giving an opportunity to manipulate the performance report (Richardson, 2000 and Morris, 1987). The failure of some companies and the emergence of the financial malpractice show poor corporate governance practices (Sabeni, 2005). Good corporate governance is necessary to encourage the creation of a market that is efficient, transparent and consistent with the legislation. Implementation of good corporate governance needs to be supported by three pillars that are interconnected, namely the state and its apparatus as a regulator, the business world as a market participant, and the public as users of business products and services.

Audit committee as a representative of one of the commissioner tasks can encourage good corporate governance practices. The role of audit committee is to assist the board of commissioners to ensure that, (a) the financial statements are presented fairly in accordance with generally accepted accounting principles, (b) internal control structure of the company is implemented well, (c) the implementation of 
internal or external audit carried out in accordance with the standards audit applicable, and (d) a follow-up audit findings done by the management. Chtourou, Bedard, \& Courteau (2001) and Klein (2002) state that the proportion of independent directors of audit committee has a negative influence on earnings management. Lin, Li and Yang (2006) do not find influence on earnings management. Meanwhile Chtourou et al. (2001); Xie et al. (2003); Bedard, Chtourou, \& Courteau (2004), find that audit committee whose skills in finance negatively effect on earnings management.

Chtourou et al. (2001) and Xie et al. (2003), state that more active audit committee will be more effective to monitor earnings management, while Bedard et al. (2004); Yang \& Krishnan (2005); Lin et al. (2006) do not find significant effect in the activity of the audit committee on earnings management. Research of Yang \& Krishnan (2005) and Lin et al. (2006) find that size of the audit committee negatively influences on earnings management and Zhai (2006) finds that size of the audit committee has a positive effect on earnings management.

Ownership structure will influence the information presented in the financial statements. The greater stock ownership by the public, then the more the information disclosed in the annual report. Public shareholders sought to monitor the behaviour of company managers in running the company, so as to create a transparency that is a principle of good corporate governance. As well as on companies with foreign ownership, so increasingly diverse information needed that cause voluntary disclosure will also increase (Putra, 2012). Institutional ownership is another part of corporate governance, because the institutions have the resources, ability and opportunity to monitor and discipline the managers to be more focused on the firm value (Siregar \& Utama, 2005). Del Guercio and Hawkins (1999) and Hartzell and Starks (2003) in Tehranian, Cornett, Marcus, \& Saunders (2006) find evidence which state that control measures undertaken by a company and institutional investors can restrict the behaviour of the manager. Managerial ownership is the ownership of shares which is owned by the manager. From the point of view of accounting theory, earnings management is largely determined by the motivation of the company manager, ownership of a manager will also determine the policy and decision-making on the accounting methods applied to the companies they manage. Therefore, it can be said that a certain percentage of stock ownership by management tend to influence earnings management action (Boediono, 2005).

This study aims to determine whether audit committee and ownership structure will have effect on earnings management in manufacturing companies listed in the Indonesia Stock Exchange (BEI). It is important to be investigated because all this time the public consider that companies in the IDX perceived as a company that carries out good corporate governance practices, but what is encouraging companies do this good practice is still common lead to long discussion when it seen from the results research. So that, it is expected that this study would be able to answer whether it is right that good corporate governance practices which will reduce earnings management practices is obtained from the audit committee that carry out their duties effectively and ownership structure of a company.

Agency problem arises because of a conflict of interest between shareholders and manager, because maximum utility does not meet between them. (Jensen \& Meckling, 1976), state that managers as company managers are more aware of internal information and the company's prospects in the future than the owner. 
So there is a great possibility that managers do not always act for the sake of owner best interests. Watts \& Zimmerman (1990) and (Ujiyantho, 2007) explain that agency theory known as information asymmetry. This information asymmetry arises as a result of information distribution that is not same between owners and managers. There are two concepts of accruals in earnings management, that is: discretionary accrual and nondiscretionary accrual. Discretionary accrual is the recognition of income or expenses accrual that are free, not regulated and the choice of management policy. According to Scott (1997) in Surifah (2001), discretionary accrual is a way to reduce profit reporting that are difficult to be detected through the manipulation of accounting policies relating to accruals, for example by increasing the cost of amortization and depreciation, recording great liabilities over the product guarantees, contingency and rebates and recording outdated inventory. Non-discretionary accrual is the recognition of a reasonable profit accrual, which is submissive to a standard or generally accepted accounting principle. Non-discretionary accruals is a reasonable accrual, and if it violated will influence the quality of financial statements (unreasonable), therefore form of accrual analyzed in this research is a form of discretionary accrual that is abnormal accrual and the choice of management policy in the selection of accounting methods.

The main issue in the implementation of good corporate governance is how managers present profit information to the parties concerned to make investment decisions in a company and uses that information to determine the investment decisions. In particular, the decision to make investments related to the relationship between the company's management and stakeholders, so it is needed a good corporate governance to control the behaviour of managers in order to act not only for their benefit, but also have to equate the interests between the owners of the company and managers.

Audit committee is often referred to as one of the successes of corporate governance. Audit committee is a subset of the board of commissioners and has the responsibility for overseeing the company's financial reporting process (Klein, 2002) and improving internal control procedures, external reporting and corporate risk management. The audit committee also plays an important role as a channel to facilitate communication between the board of commissioners, external auditors and internal auditors.

Public ownership indicates the amount of private information that must be distributed by managers to the public. The private information is internal information that is originally only known by the manager, such as standard used in the measurement of company performance, the existence of bonus plan, and so on (Rosma, 2007) in Nur'aeni (2010). Institutional ownership can be defined as the proportion of shares that distributes owned by other institutions outside the company, such as banks, insurance companies, investment companies, pension funds and others at the end of the year that measured in percentage (Wahidahwati, 2002). Siregar \& Utama (2005) in their study define institutional ownership as stock ownership by financial institutions such as insurance companies, banks, pension funds, and investment banking. (Rezaee, 2007) defines that institutional ownership is the insurance companies, public and private pension funds, investment trusts, mutual funds, and groups of investment management. If institutional investors are not satisfied with the performance of management, then they can sell (Murni \& Andriana, 2012). 
By increasing stock ownership by managers, managers are expected to act in accordance with the desire of the principals as the managers will be motivated to improve the performance. Jensen \& Meckling (1976) state that to minimize agency conflict is by improving managerial ownership in the company. Ross et al (1999) state that the bigger the management ownership in the company, then the management will tend to try improving its performance for the benefit of shareholders and for their own interests. So agency conflict are assumed to be lost if a manager is also as an owner. The bigger the proportion of management ownership in the company, then the management tend to try harder for the benefit of shareholders that are also included himself.

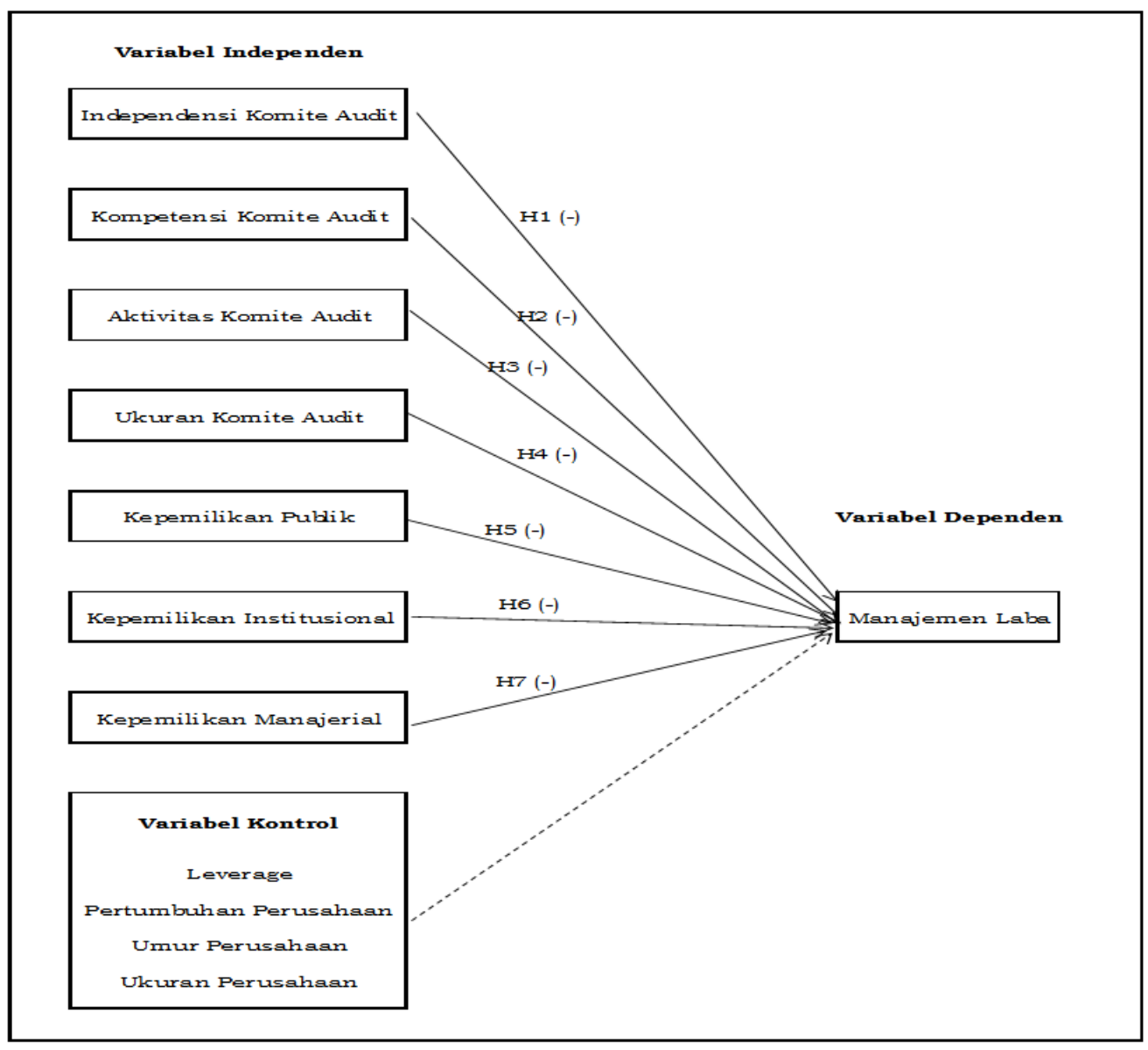

Figure 1

Research Model

\section{METHODS}

The population in this study was all manufacturing companies listed on the Indonesia Stock Exchange (BEI) by date January 1, 2007 until December 31, 2012. Selection of manufacturing companies due to the biggest proportion in Indonesia Stock Exchange (BEI) were companies that carried out business in the manufacturing field, so that manufacturing companies had a significant role in influencing the enterprise and business in Indonesia. Year election from 2007 until 2012 had background that in 2008 in Indonesia 
experienced a financial sector crisis that was feared sparking the managers of the companies to undertake dysfunctional action so it was expected that the role of audit committee and ownership structure could give conviction that dysfunctional actions did not happen.

The sampling technique in this study was conducted using purposive sampling method with the aim to obtain samples of representative in accordance with the criteria determined, namely: Manufacturing companies listed consistently in the Indonesia Stock Exchange per January 1, 2007 up to per December 31, 2012. Manufacturing companies that published annual reports in the period of 2007-2012 which were available on the Indonesian Capital Market Directory (ICMD), www.idx.co.id or the company's website. After selecting the sample on manufacturing companies listed on the Indonesia Stock Exchange, it was obtained samples that met the criteria numbered 11 companies with 66 units of analysis for the five years of observation.

In this study, dependent variable used was earnings management that was proxied by discretionary accrual. This study used the modified Jones model that has been used extensively in previous research to measure earnings management. Jones (1991), DeFond and Jiambalvo, (1994) and Butler et al., (2004) in (Lin, Hutchinson, \& Percy, 2009) used the modified Jones model as a proxy for earnings management. This model was used because it was considered the best model in detecting earnings management (Siallagan and Machfoedz 2006) in Putri (2011).

To get discretionary accrual value, it was conducted by calculating the following steps:

Calculating total accrual with equation :

Total Accrual $(\mathrm{TAC})=$ net income after tax - cash flow from operating

Calculating accrual value with multiple linear regression equation which based ordinary least square (OLS) as follows:

$\mathrm{TAC}_{\mathrm{t}} / \mathrm{A}_{\mathrm{t}-1}=\mathrm{a}_{1}\left(1 / \mathrm{A}_{\mathrm{t}-1}\right)+\mathrm{a}_{2}\left(\Delta \mathrm{REV}_{\mathrm{t}} / \mathrm{A}_{\mathrm{t}-1}\right)+\mathrm{a}_{3}\left(\mathrm{PPE}_{\mathrm{t}} / \mathrm{A}_{\mathrm{t}-1}\right)+\mathrm{e}$

Explanation :

TAC $_{\mathrm{t}}=$ Total accrual of company $\mathrm{i}$ in the period $\mathrm{t}$

$\mathrm{A}_{\mathrm{t}-1} \quad=$ Total asset for sample of the company $\mathrm{i}$ in year $\mathrm{t}-1$

$\mathrm{REV}_{\mathrm{t}} \quad=$ Changes in the sales of company $\mathrm{i}$ from year $\mathrm{t}-1$ to year $\mathrm{t}$

$\mathrm{PPE}_{\mathrm{t}} \quad=$ Fixed assets (property, plant and equipment) of company year $\mathrm{t}$

By using regression coefficients above, then calculating the value of non discretionary accrual (NDA) which can be calculated with formula:

$\mathrm{NDA}_{\mathrm{t}}=a_{1}\left(1 / \mathrm{A}_{\mathrm{t}-1}\right)+\alpha_{2}\left(\left(\Delta \mathrm{REV}_{\mathrm{t}}-\Delta \mathrm{REC}_{\mathrm{t}}\right) / \mathrm{A}_{\mathrm{t}-1}\right)+a_{3}\left(\mathrm{PPE}_{\mathrm{t}} / \mathrm{A}_{\mathrm{t}-1}\right)$

Explanation :
$\mathrm{NDA}_{\mathrm{t}}=$ Non discretionary accrual in year $\mathrm{t}$
$\Delta \mathrm{REC}_{\mathrm{t}}=$ Changes in receivables of company $\mathrm{i}$ from year $\mathrm{t}-1$ to year $\mathrm{t}$
$a=$ Fitted coefficient obtained from regression result on the calculation total accrual

Calculating the value of discretionary accrual (DAC) with equation: 
$\mathrm{DAC}_{\mathrm{t}}=\left(\mathrm{TAC}_{\mathrm{t}} / \mathrm{A}_{\mathrm{t}-1}\right)-\mathrm{NDA}_{\mathrm{t}}$

Explanation :

DAC $_{\mathrm{t}}=$ Discretionary accrual on the company $\mathrm{i}$ in the period $\mathrm{t}$

Audit committee consists of at least one member of the independent commissioner and at least two other members come from outside the issuer or public company. The measurement of this variable used the percentage between independent members according to the provisions of Capital Market Audit Agency (Bapepam) (2003) to the total members of the audit committee.

An audit committee that consists of at least one member who has competency in the financial sector will be more effective in detecting material misstatements in financial reporting. Financial competencies here are not related to educational background, but related to the experiences that have. This variable was measured by finding the percentage of the number of audit committee members that had skills in financial sector on the overall number of audit committee members.

In this study, the activities of the audit committee stated in the attendance frequency of the audit committee meeting conducted annually. Audit committee had work guidelines as outlined in the Guidelines for Audit Committee by Capital Market Audit Agency (BAPEPAM). The audit committee must convene a meeting at least in one year at least equal to the minimum requirements of commissioner board meetings that was set in the article of association, to discuss the financial reporting with external auditors. Each meeting of the audit committee noted in the minutes of meetings, signed by all members of the audit committee were attended. This variable was measured by the number of meetings held by the audit committee during the year.

In this study, size of the audit committee is the number of members contained in an audit committee. Based on the Circular Letter of the Directors of PT. The Jakarta Stock Exchange No. SE-008 / BEJ / 12-2001 dated December 7, 2001 and the Guidelines for the Establishment of the Audit Committee according to Market Audit Agency (Bapepam) Number IX.I.5 year 2004, concerning the membership of the audit committee, stated that the number of the audit committee members was at least three (3) members, including the chairman of audit committee. This variable was measured by looking at the number of audit members.

Public ownership is the number of company stock owned by public shareholders. Public ownership was measured by the number of shares proportion owned by the public divided by the number of shares issued by the company. Institutional ownership is the number of company stock owned by institutional shareholders. Institutional ownership was measured by the proportion of shares owned divided by the number of shares issued by the company. Managerial ownership is the number of company stock owned by the manager. Managerial ownership was measured by the proportion of shares owned by managers divided by the number of shares issued by the company.

Leverage (LEV) formulated with long-term debt plus current liabilities divided by total assets. Company's growth was measured by sales growth from operational activities of the company for one year (Lai, 2006). SALESGROWHT calculated from total sales in year $\mathrm{t}$ minus total sales in year $\mathrm{t}-1$ divided by the total sales of year t. Company age (AGE) was measured based on the number of years since the company 
was founded (Lai, 2005). Company size was denoted by LSIZE that proxied by natural logarithm from the total assets of the company at the end of the year (Ningsaptiti \& Hidayat, 2010).

The model used to examine the hypothesis in this study was a general model of multiple regression equation. The models in this study are as follows:

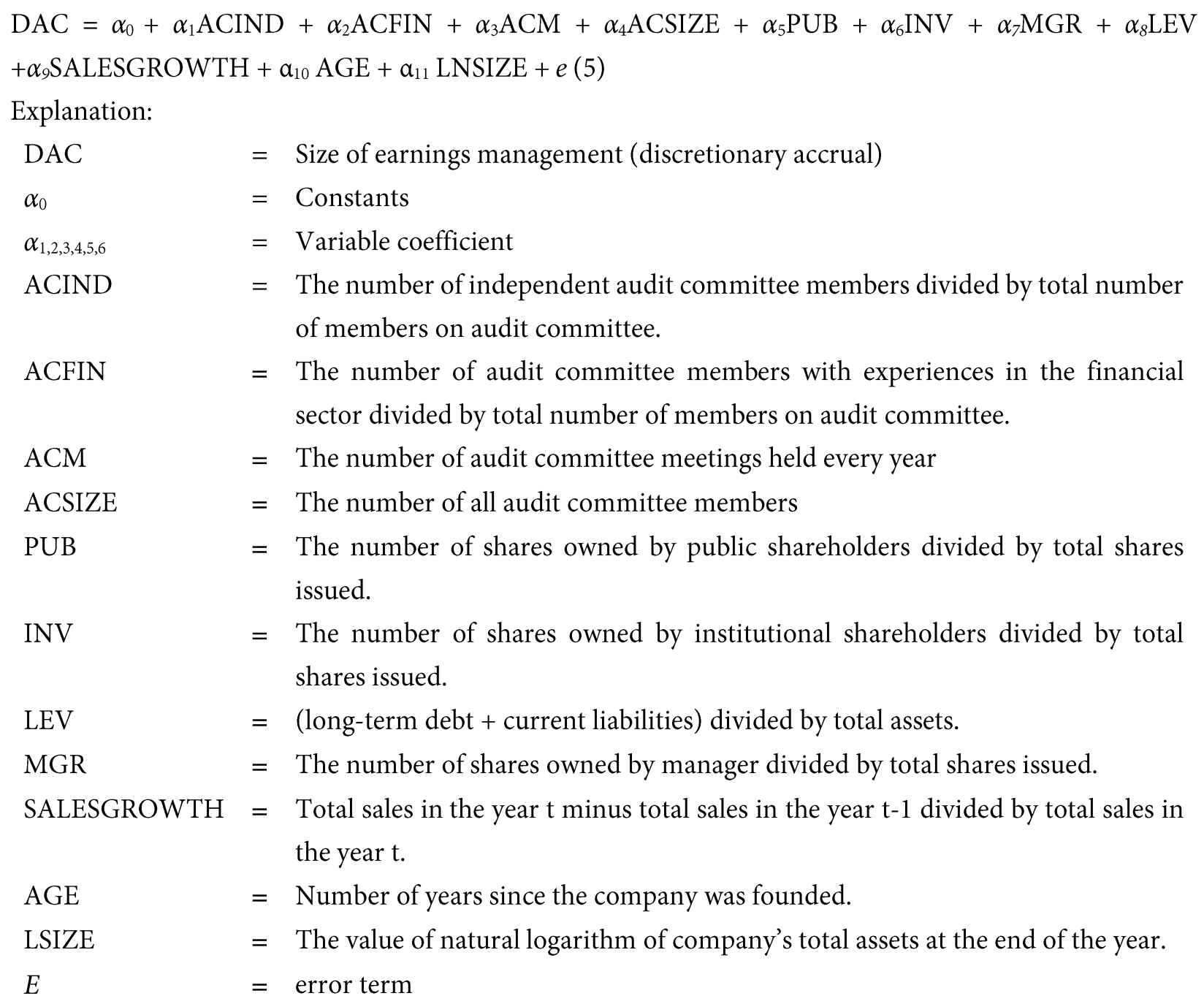

\section{RESULTS AND DISCUSSION}

Based on descriptive statistical analysis obtained the description of the sample in table 1:

Table 1. Descriptive statistics

\begin{tabular}{llllll}
\hline & N & Minimum & Maximum & Mean & Std. Deviation \\
\hline DAC & 66 & -0.39681 & 0.25978 & -0.12506 & 0.09826 \\
ACIND & 66 & 0.333 & 0.667 & 0.356 & 0.07672
\end{tabular}




\begin{tabular}{llllll} 
ACFIN & 66 & 0.25 & 1.00 & 0.63763 & 0.26854 \\
ACM & 66 & 2.00 & 15.00 & 6.07576 & 3.31110 \\
ACSIZE & 66 & 3.00 & 4.00 & 3.04545 & 0.20990 \\
PUB & 66 & 0.0352 & 0.4454 & 0.22063 & 0.12918 \\
INV & 66 & 0.0367 & 0.8650 & 0.41121 & 0.23914 \\
MGR & 66 & 0.0001 & 0.70 & 0.06729 & 0.14908 \\
LEV & 66 & 0.03786 & 0.78107 & 0.38764 & 0.20722 \\
SALESGROWTH & 66 & -0.71636 & 0.85204 & 0.13376 & 0.19623 \\
AGE & 66 & 12.00 & 61.00 & 36.77273 & 12.07769 \\
LNSIZE & 66 & 24.56205 & 31.35694 & 27.91858 & 1.68629 \\
\hline
\end{tabular}

Source: Data processed, 2015

Regression model would be declared good and could be done if it met the classical assumption test that was normality test, multicollinearity test, and heteroscedasticity test. And this study has met the classical assumption test, as shown in table 2 below:

Table 2. Summary of Classical Assumption Test

Classical Assumption Test

\begin{tabular}{lllll}
\hline Testing Result & Tolerance & VIF & Glejser & $\begin{array}{c}\text { Normality } \\
\text { Kolmogorov-smirnov } \\
\mathbf{0 , 8 0 5}\end{array}$ \\
\hline Audit Committee Independence & 0,351 & 2,848 & 0,734 & \\
Audit Committee Competency & 0,598 & 1,673 & 0,510 & \\
Audit Committee Activities & 0,338 & 2,958 & 0,206 & \\
Audit Committee Size & 0,526 & 1,899 & 0,153 & \\
Public Ownership & 0,563 & 1,775 & 0,053 & \\
Institutional Ownership & 0,458 & 2,183 & 0,558 & \\
Managerial Ownership & 0,513 & 1,949 & 0,318 & \\
Leverage & 0,600 & 1,667 & 0,517 & \\
Company Growth & 0,958 & 1,044 & 0,679 & \\
Company Age & 0,258 & 3,894 & 0,080 & \\
Company Size & 0,306 & 3,267 & 0,887 & \\
\hline
\end{tabular}

Source: Data processed, 2015

The influence of audit committee independence to earnings management, showed a negative and significant result. Members of independent audit committee would ensure a higher quality of financial reporting. Because the members were more independent, then the quality of financial reporting by companies could be more trustworthy. Therefore, the independence which was owned by audit committee 
could minimize earnings management. This study was in accordance with research conducted by Chtourou et al. (2001) and Klein (2002) who found that the proportion of independent directors influenced on earnings management. In addition, research conducted by Zheng and Liu (2008) showed that the presence of audit committee and audit committee independence influenced negatively on earnings management.

The influence of audit committee competency on earnings management showed a negative and insignificant result. This means that the competency of the audit committee as indicated by the proportion of audit committee members who were expert in the financial sector could not improve the supervisory function of the owner of the company to the management. Viewed in table 1, the competence of the audit committee did not influence significantly on earnings management, it might be possible because the audit committee did not perform its functions and its role effectively caused by the company that became sample had audit committee members of three which meant that only one of the three members was a member with skills in the finance while the assets of the company are very large so doing supervision to the management which prepared financial statements on a large asset management became a quite difficult thing. This study did not support the research conducted by Chtourou et al. (2001); Xie et al. (2003); Bedard, et al. (2004); and Carcello, Hollingsworth, Klein, \& Neal (2006), nevertheless it supported research conducted by Kusumastuti et.al (2007) and Pamudji \& Trihartati (2009).

The influence of audit committee activity on earnings management showed a positive and insignificant result. Activeness of the audit committee members that was measured by using the number of meetings held by the audit committee was not able to influence earnings management. This was presumably due to the number of meetings held by the audit committee did not focus in discussing the problems that occurred relating to the establishment of good corporate governance. The audit committee that often held meeting was not necessarily in the meeting could produce decisions or regulations that were able to minimize earnings management (Nabila, 2013). The result of this study was in accordance with the results of the research conducted by Putri (2011) and Nabilla (2013) which showed that the number of audit committee meeting did not have a significant effect on earnings management.

The influence of audit committee size to earnings management showed a negative and significant result. This means that the size of the audit committee was able to perform its role effectively. Size of the audit committee that was larger would be able to improve supervisory function of the audit committee to the management. Large audit committee would provide access to greater resources and managerial talents, so as to provide more effective supervision. Hence, the owners felt that the quality of financial reporting by management assured. The results of this study supported the research conducted by Yang and Krishnan (2005) and Lin et al. (2006) found that size of the audit committee negatively influenced on earnings management. The influence of public ownership on earnings management showed a negative and INsignificant result. It meant that a much larger percentage of ownership owned by the public was not able to conduct maximum supervision to earnings management. This could be possible because of small public ownership in samples companies that only had public ownership of 0.22063 or $22.06 \%$. So, with public ownership that was relatively small then public ownership did not have enough power to conduct 
supervision on earnings management that conducted by the manager. Furthermore, according to Azlina (2012), small public ownership could not be a means of monitoring and intervention or could not give effect to the manager's discipline to act in accordance with the interests of shareholders.

The influence of institutional ownership on earnings management showed a negative and significant result. Institutional ownership was often referred to as a sophisticated investor and should be more able to use current period information in predicting future profit compared with non-institutional ownership. According to Siregar \& Utama (2005), stated if earnings management conducted was opportunistic then high institutional ownership would reduce earnings management (negatively related). The results of the research showed that institutional ownership influenced negatively on earnings management, so that it could be concluded that institutional ownership could reduce earnings management actions undertaken by managers within a company. Percentage of certain shares owned by institutions could influence the process of preparing financial statements that did not rule out the possibility of an accrualization in accordance with the interests of the management (Boediono, 2005). Del Guercio and Hawkins (1999) and Hartzell and Starks (2003) in Tehranianet al. (2006) found evidence which stated that control measures undertaken by a company and institutional investors could restrict the behaviour of the manager.

The influence of managerial ownership on earnings management showed a negative and not significant result. It was due to the number of managerial ownership in the samples companies were still relatively small, in which the results of the study indicated the average managerial ownership in the samples companies amounted to only of 0.06729 or $6.72 \%$. So, with managerial ownership that was fairly small, it could not reduce earnings management actions. The result of this study was in line with the results of research conducted by Gabrielsen et. al. (2002) in Siallagan and Machfoedz (2006) and Murbaranti (2009), which stated that there was no significant relationship between managerial ownership and earnings management.

Table 3. Summary of hypothesis testing

Independent and control variables

\begin{tabular}{llll}
\hline Hypothesis Testing & Coefficient & t value & Sig. \\
\hline Constant & 0,800 & 2,106 & \\
Audit Committee Independence & $-0,774$ & $-3,324$ & $\left.0,002^{\star}\right)$ \\
Audit Committee Competency & $-0,090$ & $-1,772$ & 0,082 \\
Audit Committee Activities & 0,010 & 1,897 & 0,063 \\
Audit Committee Size & $-0,058$ & $-0,836$ & $\left.0,007^{\star}\right)$ \\
Public Ownership & $-0,136$ & $-1,242$ & 0,220 \\
Institutional Ownership & $-0,141$ & 2,153 & $\left.0,036^{\star}\right)$ \\
Managerial Ownership & $-0,080$ & $-0,806$ & 0,424 \\
Leverage & $-0,157$ & $-2,377$ & $\left.0,021^{\star}\right)$ \\
Company Growth & $-0,025$ & $-0,451$ & 0,654 \\
Company Age & 0,004 & 2,025 & $\left.0,048^{\star}\right)$
\end{tabular}




\begin{tabular}{|c|c|c|c|}
\hline Company Size & $-0,020$ & $-1,784$ & 0,080 \\
\hline R Square & 0,373 & & \\
\hline Adjusted R Square & 0,246 & & \\
\hline F Statistics & 2,923 & & \\
\hline Significance of F Statistics & $0.004^{*}$ & & \\
\hline \multicolumn{4}{|c|}{ Dependent variable : Earnings management (discretionary accrual) } \\
\hline \multicolumn{4}{|l|}{$\mathrm{N}=66$} \\
\hline${ }^{\star}$ ) level of significance $5 \%$ & & & \\
\hline
\end{tabular}

Source: Data processed, 2015

\section{CONCLUSIONS}

This study aimed to get empirical evidence about the influence of audit committee and ownership structure to earnings management. The audit committee is measured by proxy of the independence of the audit committee, the competence of the audit committee, the activities of the audit committee, and the size of the audit committee. The ownership structure is measured by public ownership, institutional ownership and managerial ownership. Based on the results of the research and the discussion that has been done about the influence of the audit committee and ownership structure to earnings management, it can be concluded that the independence of the audit committee, the size of the audit committee and institutional ownership can reduce earnings management actions undertaken by the managers of the company. In contrast, other variables, namely: the competence of the audit committee, the size of the audit committee, public ownership and managerial ownership cannot reduce earnings management actions undertaken by the managers of the company. The implication of this study is the company can continue to maintain the independence of audit committee members and pay attention to the size of the audit committee in accordance with the needs of the company. Moreover, the proportion of institutional ownership needs attention for ownership by another institution indeed is able to control earnings management practices, yet it needs to be noticed the percentage of the ownership in order to the interests of individual owners and other stakeholders can still be maintained. For further research, it can conduct a research by using a sample that has the characteristics of managerial ownership percentage and big public ownership.

\section{REFERENCES}

Azlina, N. (2012). Analisis Faktor Yang Mempengaruhi Manajamen Laba (Studi Pada Perusahaan Yang Terdaftar di BEI). PEKBIS (Jurnal Pendidikan Ekonomi Dan Bisnis), 2(03).

BAPEPAM. (2003). Pembentukan dan Pedoman Pelaksanaan Kerja Komite Audit. Desember, Kep-41/PM.

Bédard, J., Chtourou, S. M., \& Courteau, L. (2004). The effect of audit committee expertise, independence, and activity on aggressive earnings management. Auditing: A Journal of Practice \& Theory, 23(2), 13-35.

Boediono, G. S. B. (2005). Kualitas Laba: Studi Pengaruh Mekanisme Corporate Governance dan Dampak Manajemen Laba dengan Menggunakan Analisis Jalur. Simposium Nasional Akuntansi VIII, 172-189. 
Carcello, J. V, Hollingsworth, C. W., Klein, A., \& Neal, T. L. (2006). Audit committee financial expertise, competing corporate governance mechanisms, and earnings management. Competing Corporate Governance Mechanisms, and Earnings Management (February 2006).

Chtourou, M., Bedard, S., \& Courteau, L. J. (2001). Corporate governance and earnings management. Corporate Governance and Earnings Management (April 21, 2001).

Gumanti, T. A. (2004). Earnings Management: Suatu Telaah Pustaka. Jurnal Akuntansi Dan Keuangan, 2(2), pp-104.

Gunny, K. A. (2010). The relation between earnings management using real activities manipulation and future performance: Evidence from meeting earnings benchmarks. Contemporary Accounting Research, 27(3), 855-888.

Jensen, M. C., \& Meckling, W. H. (1976). Theory of the firm: Managerial behavior, agency costs and ownership structure. Journal of Financial Economics, 3(4), 305-360.

Klein, A. (2002). Audit committee, board of director characteristics, and earnings management. Journal of Accounting and Economics, 33(3), 375-400.

Lai, L. H. Y. (2006). Are independent directors effective in lowering earnings management in China? Texas A\&M University.

Lin, J. W., Li, J. F., \& Yang, J. S. (2006). The effect of audit committee performance on earnings quality. Managerial Auditing Journal, 21(9), 921-933.

Lin, P. T., Hutchinson, M. R., \& Percy, M. (2009). The role of the audit committee and institutional investors in constraining earnings management: evidence from Chinese firms listed in Hong Kong. In Proceedings of Accounting \& Finance Association of Australia \& New Zealand Annual Conference 2009. Accounting and Finance Association of Australia and New Zealand (AFAANZ).

Murni, S., \& Andriana, A. (2012). Pengaruh Insider Ownership, Institutional Investor, Dividend Payments, dan Firm Growth Terhadap Kebijakan Hutang Perusahaan (Studi Kasus pada Perusahaan Manufaktur yang Terdaftar di Bursa Efek Jakarta). Jurnal Akuntansi Dan Bisnis, 7(1).

Ningsaptiti, R., \& Hidayat, T. (2010). Analisis Pengaruh Ukuran Perusahaan dan Mekanisme Corporate Governance Terhadap Manajemen Laba (Studi empiris pada perusahaan manufaktur yang terdaftar di BEI tahun 2006-2008). Perpustakaan FE UNDIP.

Putra, W. E. (2012). Pengaruh Size, Profitabilitas, Leverage, Kepemilikan Dalam Negeri dan Kepemilikan Asing terhadap Pengungkapan Tanggung Jawab Sosial Perusahaan (Survey pada Perusahaan Industri yang Terdaftar di Bursa Efek Indonesia). Jurnal Penelitian Universitas Jambi: Seri Humaniora, 13(2).

Rezaee, Z. (2007). Corporate governance post-Sarbanes-Oxley: Regulations, requirements, and integrated processes. John Wiley \& Sons.

Richardson, V. J. (2000). Information asymmetry and earnings management: Some evidence. Review of Quantitative Finance and Accounting, 15(4), 325-347.

Sabeni, A. (2005). Peran Akuntan dalam Menegakkan Prinsip Good Corporate Governance pada Perusahaan di Indonesia (Tinjauan Perspektif Teori Keagenan). Pidato Pengusulan Guru Besar Universitas Diponegoro.

Siregar, S. V. N. P., \& Utama, S. (2005). Pengaruh struktur kepemilikan, ukuran perusahaan, dan praktek corporate governance terhadap pengelolaan laba (earnings management). Simposium Nasional Akuntansi VIII, 480-496.

Tehranian, H., Cornett, M. M., Marcus, A. J., \& Saunders, A. (2006). Earnings Management, Corporate Governance, and True Financial Performance. Corporate Governance, and True Financial Performance (January 2006).

Ujiyantho, M. A. (2007). Asimetri informasi dan manajemen laba: Suatu tinjauan dalam hubungan keagenan. Jurnal Riset Akuntansi Indonesia, 25-37. 
Wahidahwati, W. (2002). Pengaruh Kepemilikan Manajerial dan Kepemilikan Institusional pada Kebijakan Hutang Perusahaan: Sebuah Perspektif Theory Agency. The Indonesian Journal of Accounting Research, 5(1).

Watts, R. L., \& Zimmerman, J. L. (1990). Positive accounting theory: a ten year perspective. Accounting Review, 131156.

Yang, J. S., \& Krishnan, J. (2005). Audit committees and quarterly earnings management. International Journal of Auditing, 9(3), 201-219. 